$\mathrm{DOI}$

\title{
ГІСТОЛОГІЧНЕ І ЕЛЕКТРОННО-МІКРОСКОПІЧНЕ ДОСЛІДЖЕННЯ КЕРАТОКСЕНОІМПЛАНТАТА ПРИ РІЗНИХ ВИДАХ КОНСЕРВАЦІї
}

\author{
๑М. В. ТУрчин ${ }^{1}$, К. С. Волков ${ }^{1}$, І. М. Кліщ ${ }^{1}$, Р. М. Борис ${ }^{2}$ \\ ДВНЗ «Тернопільський державний медичний університет імені І. Я. Горбачевського Моз України»' \\ ПВНЗ «Київський медичний університет УАНМ» МОЗ України
}

РЕЗЮМЕ. Досліджено структурну організацію компонентів інтактної рогівки свині та морфологічні структури кріоконсервованої рогівки без кріопротектора ікріоконсервованої рогівки з кріопротектором. Встановлено, що кріоконсервування ксенорогівки після проведення попередньої обробки в гліцерин-жовтковій суміші забезпечує високу збереженість всіх їі структурних компонентів.

КЛЮчОВІ СЛОВА: рогівка, структура, кріоконсервування.

Вступ. До сьогодні найбільш поширеним методом лікування в клініці очних хвороб $\epsilon$ пересадка нативної донорської рогової оболонки. Безперервно росте потреба в матеріалі для трансплантації, що пов'язано з гострою нестачею донорської тканини у багатьох країнах через демографічні проблеми, збільшення випадків інфекційних захворювань, широке використання рефракційної лазерної хірургії. Крім того, цей дефіцит посилюється через недосконалість законодавства і релігійні фактори $[1,5,8,9]$.

Вищевказані проблеми зумовлюють пошук нових шляхів забезпечення матеріалу для реконструктивних операцій на рогівці. В останні роки нами проведені експериментальні дослідження потенційних можливостей використання для кератопластики свинячої рогівки, яка за своїми морфологічними й імунологічними властивостями $\epsilon$ достатньо наближеною до рогівки людини.

Метою нашого дослідження було порівняти морфологічні структури консервованих різними методами рогівок (кріоконсервування рогівки без кріопротектора та кріоконсервування рогівки з кріопротектором) з нормальною рогівкою свині.

Матеріал і методи дослідження. Об'єктом дослідження були 46 свинячих рогівок. Технологія отримання донорського матеріалу була стандартною. Забір рогівок проводили в цеху забою тварин $[2,3]$ із дотриманням правил «європейської конвенції про захист хребетних тварин, які використовуються для експериментів та з іншою науковою метою [7], а також згідно з «Науковопрактичними рекомендаціями із утримання лабораторних тварин та роботи з ними» [4]. Ксенорогівки поділили на групи і зберігали при різних умовах і в різних розчинах. Першу групу становили інтактні рогівки. Другу групу утворювали кріоконсервовані рогівки, матеріал для цього поміщали в рідкий азот $\left(t-120^{\circ} \mathrm{C}\right)$. Третю групу складали рогівки, які в стерильних умовах поміщали в по- ліетиленові пакети і заливали консервантом, що включав 100 мл дистильованої підігрітої до $40^{\circ} \mathrm{C}$ води, 11,5 мл лактози, 5 мл гліцерину та жовток курячого яйця 20 мл. У консерванті розправляли рогівку, видаляли з пакетів повітря і герметизували їх. Для еквілібрації матеріалу пакети поміщали в холодильник на 3 години при температурі +4 $+6^{\circ} \mathrm{C}$. Після цього їх переносили в пару рідкого азоту на 10 хвилин при температурі $-120{ }^{\circ} \mathrm{C} 3$ наступним переміщенням для зберігання до чану з рідким азотом.

Для проведення гістологічних досліджень забирали шматочки рогівки свині, фіксували їх у 10 \% нейтральному формаліні. Подальшу обробку матеріалу з наступною заливкою в парафінові блоки здійснювали згідно з загальноприйнятими методиками [6]. Отримані на санному мікротомі зрізи забарвлювали гематоксиліном-еозином.

Гістологічні препарати вивчали за допомогою світлового мікроскопа SEO SCAN та фотодокументували за допомогою відеокамери Vision CCD Сатега з системою виводу зображення з гістологічних препаратів.

Забір матеріалу для електронно-мікроскопічних досліджень проводили також згідно з загальноприйнятою методикою [6]. Відпрепаровані маленькі шматочки рогівки фіксували у 2,5 \% розчині глютаральдегіду з активною реакцією середовища $\mathrm{pH} 7,2-7,4$, приготовленому на фосфатному буфері. Фіксований матеріал через 60 хвилин переносили у буферний розчин і промивали впродовж 20-30 хвилин. Постфіксацію здійснювали 1 \% розчином чотириокису осмію на фосфатному буфері впродовж 60 хвилин, після чого проводили його дегідратацію у пропіленоксиді та заливали в суміш епоксидних смол з аралдитом.

Ультратонкі зрізи, виготовлені на ультрамікротомі LKB-3 (Швеція), контрастували 1 \% водним розчином уранілацетату та цитратом свинцю згідно з методом Рейнольдса і вивчали в електронному мікроскопі ПЕМ-125K. 
Огляди літератури, оригінальні дослідження, погляд на проблему

Такі методики досліджень дають можливість вивчити структурну організацію компонентів рогівки, а також характер і глибину морфологічних змін, послідовність розвитку деструктивних і регенераторних процесів.

Результати й обговорення. Інтактна рогівка свині має типову структурну організацію. Мікроскопічно її складають п'ять шарів: передній епітелій, власна речовина, передня і задня пограничні пластинки (мембрана Боумена та мембрана Десцемета) та задній епітелій (ендотелій).

Зовнішній шар утворений багатошаровим плоским незроговілим епітеліем, що складається з базального, остистого та плоского пластів епітеліоцитів. Мікроскопічно при забарвленні препаратів гематоксиліном і еозином спостерігається хвиляста базальна мембрана у вигляді рожевої стрічки. Досить широка передня погранична пластика також відмежовує передній епітелій від власної речовини.

Власна речовина рогівки побудована з щільної сполучної тканини, яка включає три компоненти: колагенові пластинки, подовгастої форми фіброцити і основну речовину. Колагенові пластини орієнтовані поздовжньо і занурені в аморфну речовину, яка в складі має протеоглікани. Це забезпечує прозорість рогівки (рис. 1).

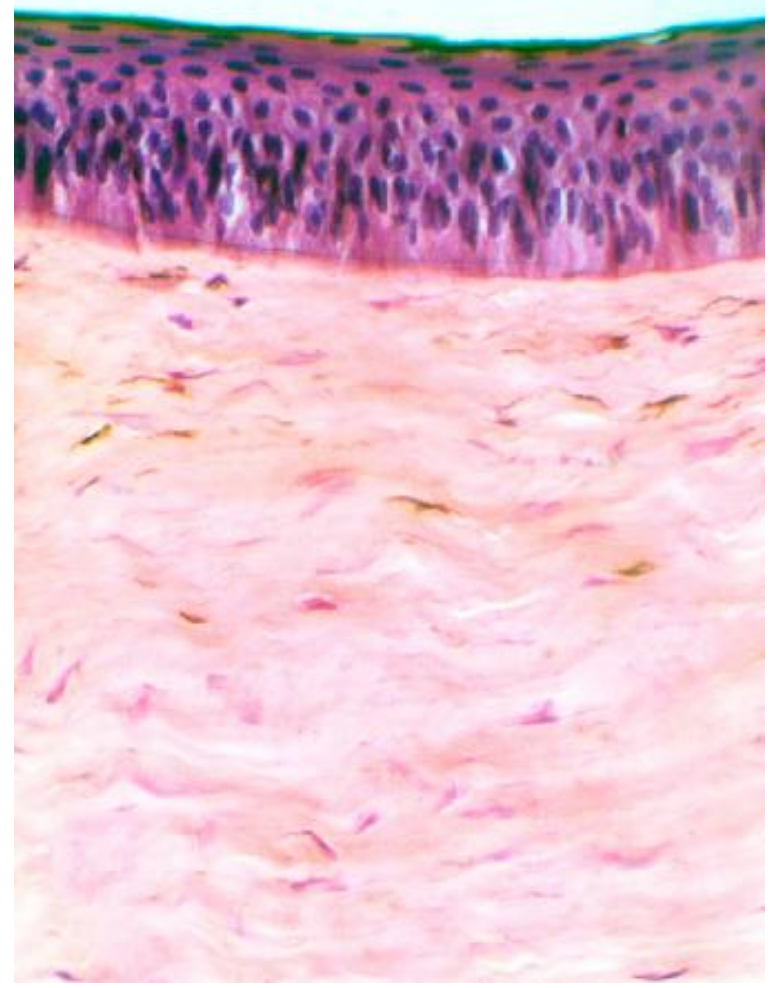

Рис. 1. Мікроскопічна будова ксенорогівки тварини інтактної групи: 1 - передній епітелій, 2 - власна речовина, 3 - передня погранична пластинка. Забарвлення гематоксиліном-еозином. $\times 200$.
Задня погранична пластинка у вигляді безструктурної рожевої смужки обмежує задню поверхню власної речовини ксенорогівки. Задній епітелій ксенорогівки представлений одношаровим плоским епітелієм. Епітеліоцити щільно прилягають одна до одної та до задньої пограничної пластинки. У них добре виражені еліпсоподібної форми базофільні ядра, а рожевого кольору, гомогенна цитоплазма має помірний об'єм.

Проведені детальні гістологічні дослідження рогівки свині інтактної групи виявили специфічність її структурної організації. Вони будуть служити контролем і необхідні для зіставлення та інтерпретації даних, отриманих при різних методах консервування ксенотрансплантатів рогівки.

Проведені мікроскопічні дослідження рогівки після ії кріоконсервування без попередньої обробки кріопротектором встановили, що вона зберігає загальну структурну організацію. Добре структуровані виражені шари переднього епітелію, пограничні мембрани і власна речовина рогівки (рис. 2).

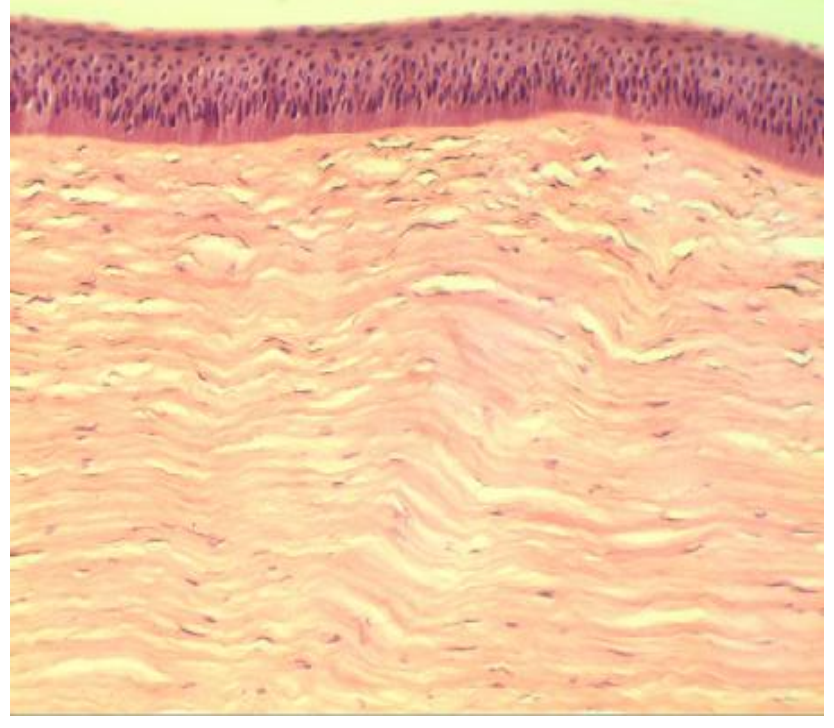

Рис. 2. Мікроскопічна будова кріоконсервованої в рідкому азоті ксенорогівки: 1 - передній епітелій, 2 передня погранична пластинка, 3 - власна речовина. Забарвлення гематоксиліном еозином. $\times 100$.

Передній епітелій включає окремі кератиноцити з базофільними, пікнотичними ядрами, частина клітин базального та остистого шарів має оптично світлу цитоплазму, збільшуються міжклітинні проміжки. Передня погранична пластинка збережена, проте наявні ділянки відшарування від неї епітеліальної пластинки.

Власна речовина рогівки за умов звичайного кріоконсервування має між сполучнотканинними пластинками подовгастої форми світлі порожнини. Фіброцити зберігають впорядковане роз- 
Огляди літератури, оригінальні дослідження, погляд на проблему

міщення, мають витягнуту, відростчасту форму, темно забарвлені ядра і цитоплазму. Задня погранична пластинка незмінена, відмічаються невеликі ділянки відшарування заднього епітелію від неї. Ендотелій рогівки представлений одношаровими плоскими клітинами, що мають базофільні еліпсоподібної форми ядра, слабо рожеву цитоплазму. Проте частину клітин складають невеликі базофільні ядра та світла цитоплазма.

Субмікроскопічні дослідження кріоконсервованої рогівки виявили зміни у всіх їі структурних компонентах. Для багатьох епітеліоцитів переднього епітелію характерна електронно-світла цитоплазма, помірне пошкодження органел.

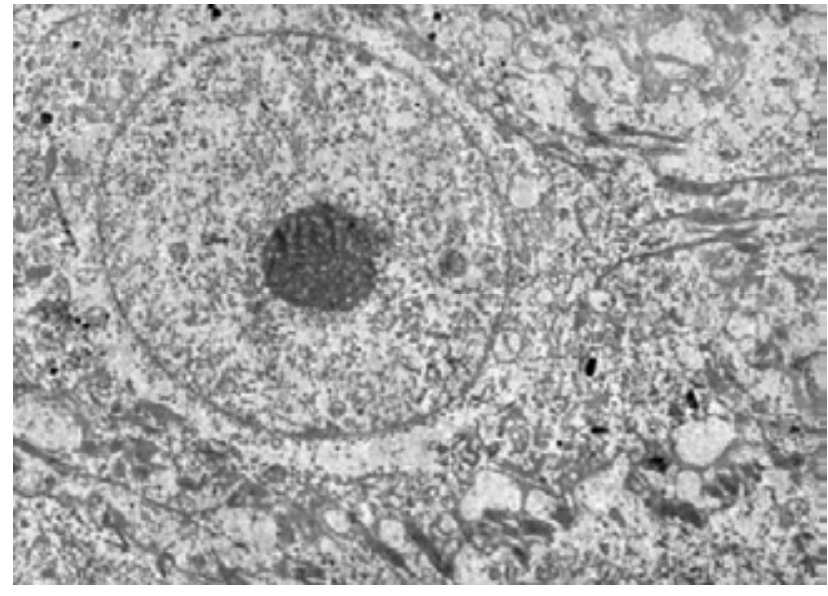

Рис. 3. Субмікроскопічні зміни епітеліоцитів переднього епітеліального шару кріоконсервованої рогівки свині: 1 - округло-овальні ядра, 2 - невелике ядерце, 3 - електронно-світла гіалоплазма, 4 - деструкція органел, 5 - збільшені міжклітинні простори, 6 - десмосоми. $\times 9000$.

Подовгастої форми фіброцити мають вузькі відростки. їх ядра невеликі, з інвагінаціями каріолеми. В осміофільній цитоплазмі наявні пошкоджені органели.

Передня і задня пограничні пластинки виглядають гомогенними, мікрофібрилярні структури в них погано контуруються.

Проведені мікроскопічні дослідження рогівки після її кріоконсервування з застосувануям кріопротектора показали високу збереженість всіх ії структурних компонентів. Передній епітелій, власна речовина, пограничні пластинки та ендотелій виглядають незміненими. Добре виражене пошарове розташування епітеліоцитів відносно базальної мембрани, розширення міжклітинних проміжків не спостерігається. Контури передньої та задньої пограничних пластинок чіткі. Власна речовина рогівки без ознак набряку, відсутні світлі порожнини між сполучнотканинними пластинками (рис. 5).
У частині епітеліоцитів остистого і базального шарів наявні вакуолеподібні структури, виявляються набряклі з просвітленим матриксом і пошкодженими кристами мітохондрії. Між епітеліоцитами спостерігаються потовщені міжклітинні простори. Також наявні клітини з пошкодженими ядерними і плазматичними мембранами (рис. 3).

У власній речовині рогівки сполучнотканинні пластинки потовщені, їх границі місцями нечіткі, а колагенові фібрили погано контуруються. В окремих ділянках власної речовини рогівки спостерігаються електронно-прозорі, світлі сполучнотканинні пластинки, у яких мікрофібрили візовані (рис. 4).

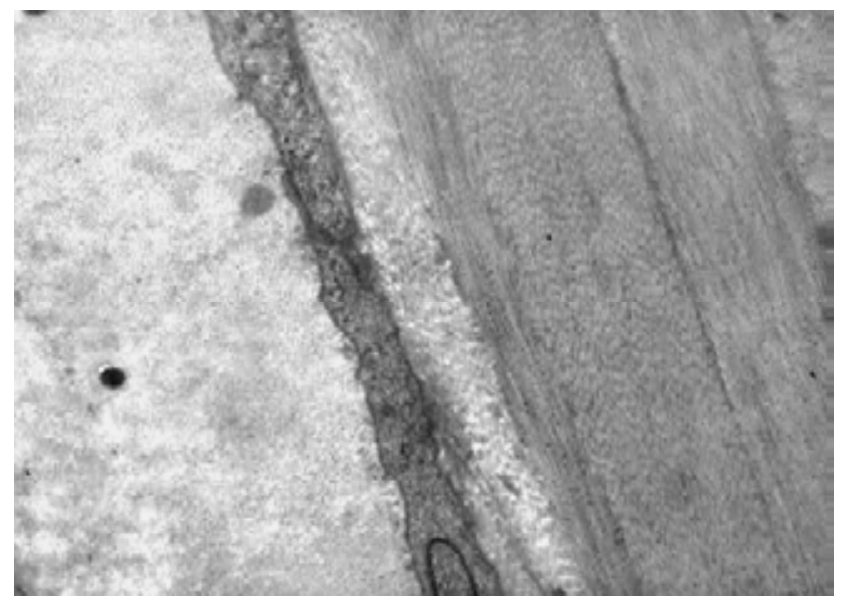

Рис. 4. Ультраструктурна організація власної речовини кріоконсервованої рогівки: 1 - подовгастий фіброцит, 2 - світлі сполучнотканинні пластинки, 3 темні сполучнотканинні пластинки. $\times 9000$.

Субмікроскопічні дослідження кріоконсервованої з використанням гліцерин-жовткової суміші рогівки показали, що у всіх її структурних компонентах спостерігаються незначні зміни. В епітеліоцитах переднього епітелію цитоплазма має невеликі світлі вакуолеподібні порожнини, які утворені за рахунок розширення канальців ендоплазматичної сітки і цистерн комплексу Гольджі (рис. 6).

Гіалоплазма має помірну електронну щільність, органел у ній небагато. Мітохондрії розташовані поодиноко, вони мають світлий матрикс і частково пошкоджені кристи. Такий стан органел свідчить про пригнічення біосинтетичних і енергетичних процесів у клітинах поверхневого шару. В цитоплазмі епітеліоцитів гірше контуруються тонофібрили, міжклітинні простори помірно розширені, високої електронної щільності десмосоми мають невеликі розміри.

Субмікроскопічно виявлено, що за умов цього методу консервації власна речовина рогівки 


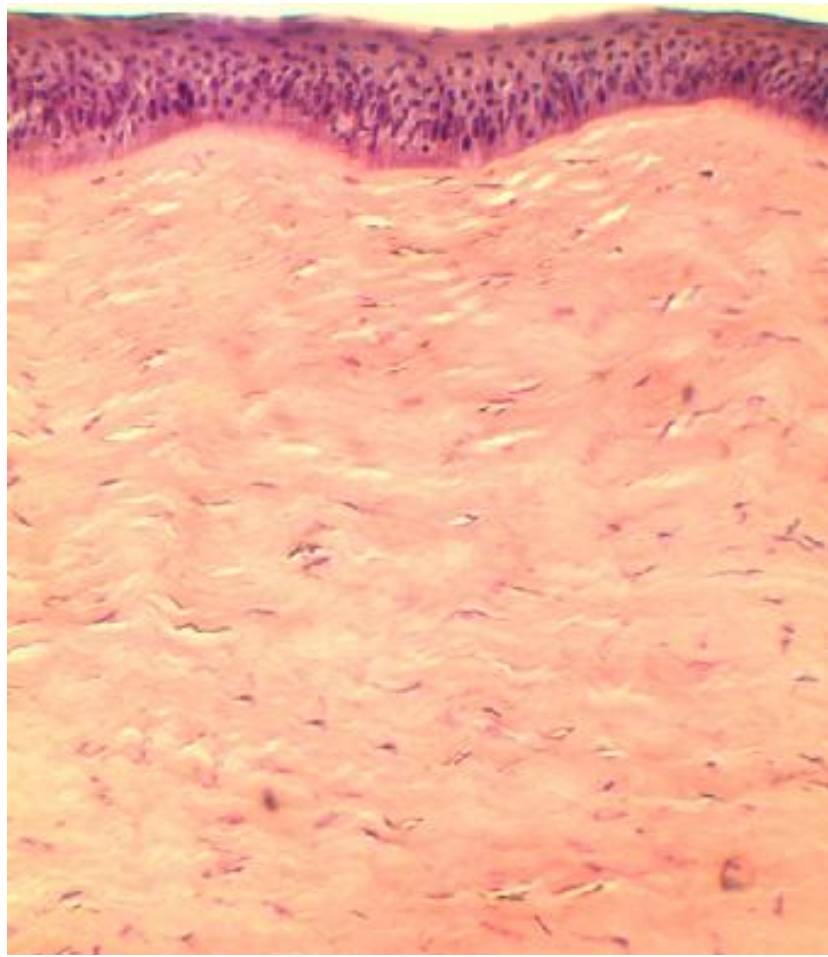

Рис. 5. Мікроскопічна будова кріоконсервованої ксенорогівки з попередньою обробкою в гліцеринжовтковій суміші: 1 - передній епітелій, 2 - передня погранична пластинка, 3 - власна речовина рогівки. Забарвлення гематоксиліном-еозином. $\times 200$.

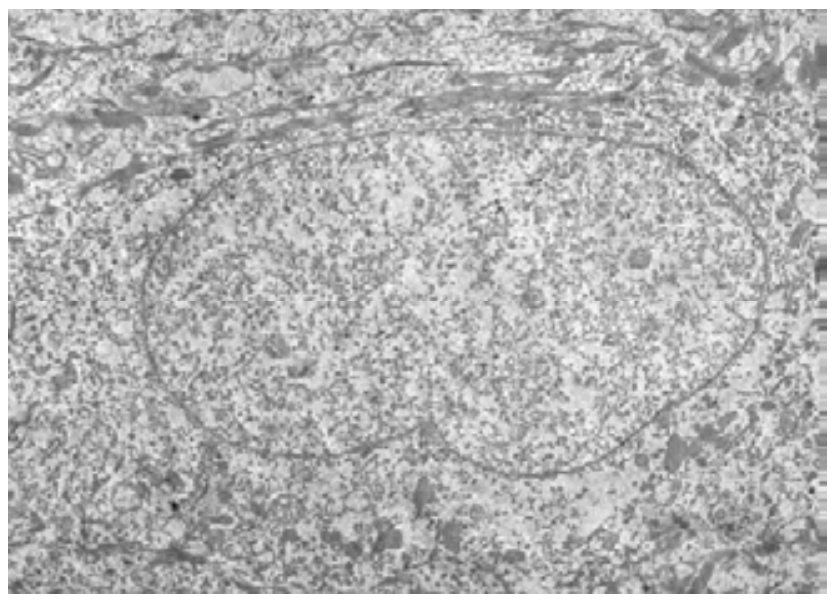

Рис. 6. Субмікроскопічний стан епітеліоцитів переднього епітелію рогівки після ії кріоконсервування з використанням гліцерин-жовткової суміші: 1-овальне ядро, 2 - цитоплазма, 3 - невеликій міжклітинний простір. $\times 8000$.

також добре зберігає властиву їй організацію. Переважна більшість пластинок добре структуровані, мають правильне розташування колагенових фібрил, лише на окремих ділянках сполучнотканинні пластинки мають ділянки просвітлення, у яких фібрили лізуються (рис. 7).

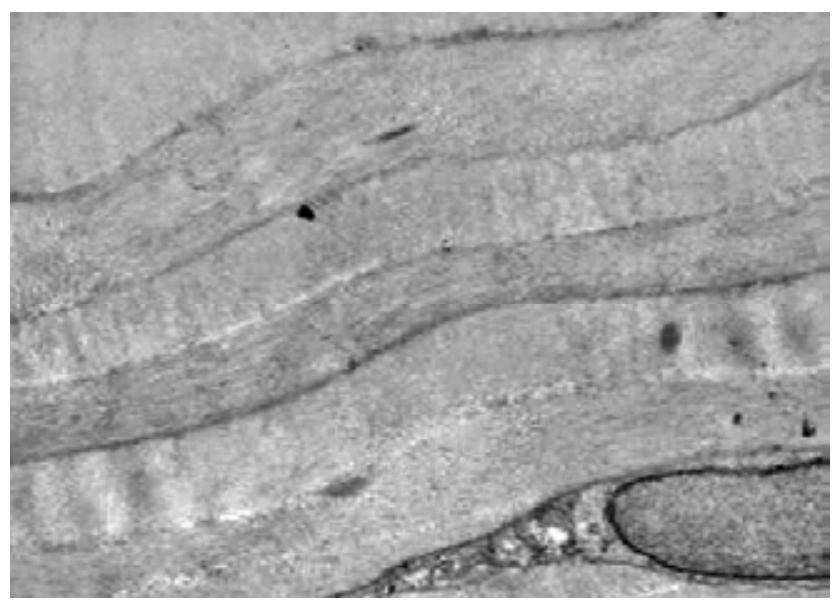

Рис. 7. Субмікроскопічний стан власної речовини рогівки після їі кріоконсервування з використанням гліцерин-жовткової суміші: 1 - подовгастої форми фібробласт, 2 - еліпсоподібне ядро, 3 - сполучнотканинні пластинки, 4 - просвітлені ділянки пластинок. ×7000.

Більшості фібробластів, що розташовані між пластинками, притаманна подовгаста форма, тонкі відростки. Їх цитоплазма осміофільна, включає мало органел. Ядра з помірною електронною щільністю каріоплазми, інвагінаціями каріолеми.

Задній епітелій рогівки при кріоконсервації після еквілібрації гліцерин-жовтковою сумішшю зберігає ультраструктуру. Овальні ядра виглядають зменшеними, каріолема нерівна за рахунок неглибоких інвагінацій. У цитоплазмі епітеліоцитів спостерігаються вузькі канальці гранулярної ендоплазматичної сітки, на поверхні їх мембран мало рибосом. Мітохондрій також небагато, вони мають округло-овальну форму і помірно набряклі, з світлим матриксом і частково пошкодженими кристами. Передня і задня пограничні пластинки виглядають незміненими.

Висновок. Гістологічні дослідження встановити задовільну збереженість структурної організації кріоконсервованої рогівки свині. Кріоконсервування ксенорогівки після проведення попередньої обробки в гліцерин-жовтковій суміші забезпечує високу збереженість всіх їі структурних компонентів. Встановлені помірні зміни переднього епітелію та власної речовини свідчать про те, що такий метод консервування можна рекомендувати для трансплантації при пошкодженнях рогівки. 
Огляди літератури, оригінальні дослідження, погляд на проблему

\section{ЛІТЕРАТУРА}

1. Активные подходы в лечении бактериальных кератитов и гнойных язв роговицы / К. П. Павлюченко, С. Ю. Могилевский, Ю. Н. Терещенко, И. Г. Зыков // Архів офтальмології України. - 2013. - Т. 1, № 1. - С. 120-127.

2. Бігуняк В. В. Консервування ауто- і ксенотрансплантанта для відновлення втраченої шкіри у опечених хворих: дис. на здобуття наукового ступеня доктора мед. наук / Бігуняк Володимир Васильович. - Тернопіль, 1994. - 275 с.

3. Бігуняк Т. В. Ультраструктура ксенодермотрансплантантів при використанні гліцерин-жовткової суміші для низькотемпературного зберігання та кріоконсервування / Т. В. Бігуняк, А. В. Довбуш, К. С. Волков // Буковинський медичний вісник. - 2001. - Т. 5, № 3-4. C. $16-17$.

4. Кожемякін Ю. М. Науково-практичні рекомендації з утримання лабораторних тварин та роботи 3 ними / Ю. М. Кожемякін. - К., 2002. - 155 с.
5. Пасечникова Н. В. Гистоморфологическое исследование роговицы кроликов после послойной трансплантации бесклеточного модуля стромы роговицы человека / Н. В. Пасечникова, В.В.Вит, И.О.Насинник // Офтальмологический журнал. - 2012. - № 5. - С. 47-51.

6. Сорочинников А. Г. Гистологическая и микроскопическая техника / А. Г. Сорочинников, А. Е. Доросевич. - Смоленск : САУ, 2000.-480 с.

7. European convention for the protection of vertebrate animals used for experimental and other scientific purposes. - Council of Europe. Strasbourg. - 1986. № $123 .-52 \mathrm{p}$.

8. Hodge C. Ocular emergencies / C. Hodge, M. Lawless // Aust. Fam. Physician. - 2008. - Vol. 37 (7). P. 506-509.

9. Keratoprosthesis surgery for end-stagecorneal blindness in Asian eyes / D. T. Pan, A. B. Tay, J. T. Theng [et al.] // Ophthalmology. - 2008. - Vol. 115. - P. 503-510.

\title{
HISTOLOGICAL AND ELECTRON MICROSCOPE STUDY OF CERATOXENOIMPLANT IN CASE OF DIFFERENT TYPES OF CONSERVATION
}

\author{
@M. V. Turchyn ${ }^{1}$, K. S. Volkov' ${ }^{1}$ I. M. Klishch ${ }^{1}$, R. M. Borys ${ }^{2}$
}

I. Horbachevsky Ternopil State Medical University' PHEI «Kyiv Medical University»?

SUMMARY. The structural components of the organization of pigs' intact cornea and morphological structure of the crioconservated cornea without crioprotectant and crioconservated cornea with crioprotectant were investigated. It was found that crioconservation of ceratoxenoimplant after pretreatment in the yolk-glycerol mixture ensures high safety of all its structural components.

KEY WORDS: cornea, structure, crioconservation. 